\title{
Evaluation of Groundwater Quality and Its Suitability for Irrigation Use on the Bank of Noyyal River at Tiruppur, Tamilnadu, India
}

\author{
K.M. Mohamed Sheriff and A. Zahir Hussain \\ Department of Chemistry, Jamal Mohamed College (Autonomous), Tiruchirappalli-20 \\ Email: azahirhussainchem@yahoo.co.in
}

\begin{abstract}
Tiruppur is a fast growing industrial city in Tamilnadu which is also known as 'Banian City' of India. The study area of Tiruppur is located at $11^{\circ} 06^{\prime} 27^{\prime \prime} \mathrm{N}, 77^{\circ} 20^{\prime} 23^{\prime \prime} \mathrm{E} / 11.1075^{\circ} \mathrm{N}$, $77.3398^{\circ} \mathrm{E}$. Geographical area of Tiruppur district is 5186.34 square kilometers. It is located on the bank of the Noyyal river, a tributary of the river Cauvery. The Noyyal river originates from Velliangiri hills in the Western Ghats and flows through Coimbatore, Tiruppur, Erode and Karur districts traversing distance of $175 \mathrm{~km}$ and confluences with the river Cauvery near Noyyal village. The textile industries in Tiruppur mostly fall under the category of small scale and cottage sector industries. The industrial units are scattered in and around Tiruppur including the neighboring areas. The concentrations of physico-chemical parameters and irrigation water quality parameters were analyzed. Based on the results, all the ground water samples can be used for the irrigation purposes.
\end{abstract}

Key words: Groundwater, irrigation, SAR, RSC and kelly ratio

\section{Introduction}

In India, about $50 \%$ of the total irrigated area is dependent on groundwater irrigation and according to FAO groundwater constitutes about $53 \%$ of the total irrigation potential of the country and sixty percent of irrigated food production is from groundwater (Vasanthavigar et al., 2012). Groundwater quality has been deteriorating over the last few decades due to the massive rise in rate of industrialization and population. Various environmental indices and parameters are now being used to ascertain the quality of water leading to the determination of its suitability for domestic and irrigation purposes. Evaluation of groundwater quality is a necessary and immediate task for present and future groundwater quality researchers. Several researchers evaluated the suitability of groundwater for irrigation quality. Hence the present study focuses on ascertaining the irrigational suitability and potability standards of ground water.

\section{Materials and Methods}

The place of study at which water samples are collected is referred to as "Stations". The ground water samples are collected during summer and rainy seasons of 2013-2015. Ten stations are selected. They are represented as Authupalayam (S1), Pallapalayam (S2), Theethangadu (S3), Mangalam (S4), Sulthanpettai (S5), Karuvampalayam (S6), Vijayapuram (S7), Mannarai (S8), Mudalipalayam Sidco (S9) and Ponapuram (S10). The samples are collected in each station using sampling techniques. The samples were analyzed for Physico-chemical parameters using standard procedures (APHA., 1995). From these data, the irrigational quality parameters such as Sodium adsorption ratio (SAR), Sodium percentage (\% Na), Residual sodium carbonate (RSC), Magnesium ratio (MR), Permeability index (PI), Kelly's ratio (KR) and Chloro-Alkaline Indices (CAI-1 and CAI -2) were calculated for ground water samples to assess the suitability for irrigation purposes. The results are tabulated in table and compared with WHO standards (WHO., 2011). The location of the study area is shown in figure 1. 


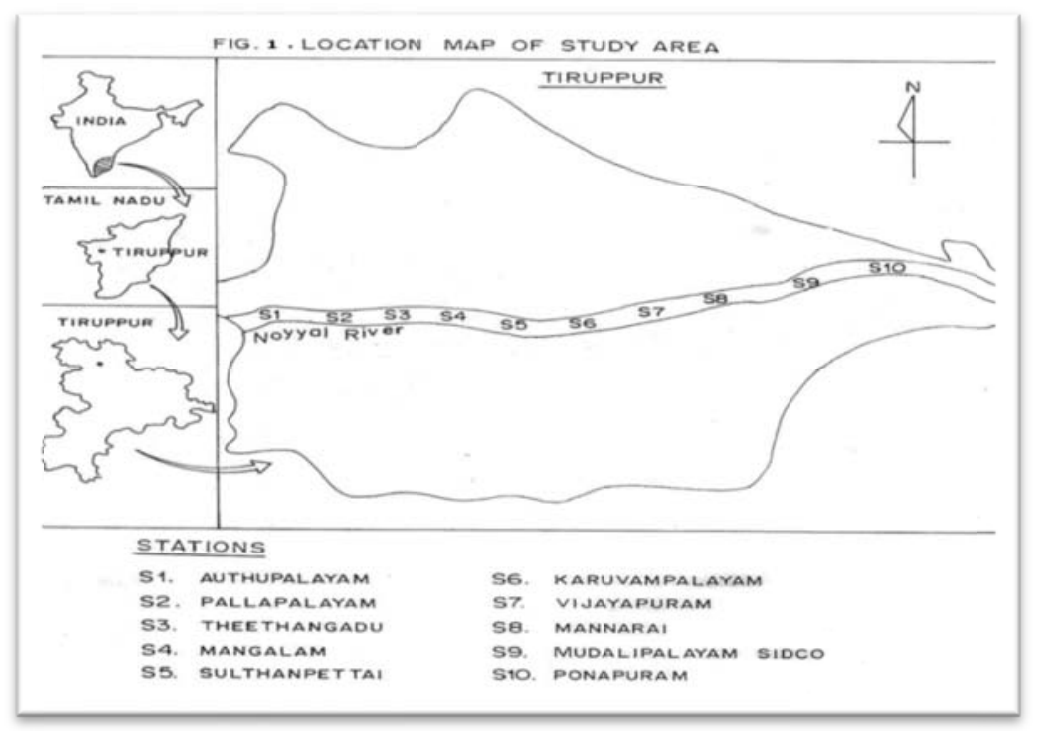

Figure 1. Location map of study area

\section{Results and Discussion}

\subsection{Residual Sodium Carbonate (RSC)}

Residual sodium carbonate (RSC) is an index of irrigation water. It is used to indicate the alkalinity hazard of soil. The RSC index is used to find the suitability of the water for irrigation in clay soils which have a high cation exchange capacity. RSC has been calculated to determine the hazardous effect of carbonate and bicarbonate on the quality of water for agriculture purpose. The values of RSC are found between the range of -8.22 and $-2.90 \mathrm{meq} / \mathrm{L}$ and -7.60 and $-3.53 \mathrm{meq} / \mathrm{L}$ for groundwater in summer and rainy seasons respectively. (Table $8 \& 9$ ). The RSC values are found in the 'Safe' category $(<1.25 \mathrm{meq} / \mathrm{L})$ at stations $1 \mathrm{~A}-10 \mathrm{~B}$ in summer and rainy seasons for groundwater samples. Hence the present study predicts that all the groundwater samples fall under the 'Safe' category which can be used for irrigation purposes (Table 1).

Table 1. Classification of groundwater samples based on RSC values.

\begin{tabular}{c|c|c|c}
\hline \multirow{2}{*}{$\begin{array}{c}\text { RSC VALUES } \\
(\mathbf{m e q} / \mathbf{L})\end{array}$} & \multirow{2}{*}{ CLASS } & \multicolumn{2}{|c}{ STATIONS } \\
\cline { 3 - 4 } & & Summer & Rainy \\
\hline$<1.25$ & Safe & $1 \mathrm{~A}-10 \mathrm{D}$ & $1 \mathrm{~A}-10 \mathrm{D}$ \\
\hline $1.25-2.5$ & Marginal & -- & -- \\
\hline$>2.5$ & Unsuitable & -- & -- \\
\hline
\end{tabular}

\subsection{Sodium Adsorption Ratio (SAR)}

The degree to which the irrigation water tends to be involved in cation exchange reaction in soil can be indicated by the sodium adsorption ratio, since sodium replaces adsorbed calcium and magnesium in soil (Dash et al., 2014). The sodium adsorption ratio (SAR) is commonly used as an index for evaluating the sodium hazard associated with an irrigation water supply. The value of SAR is found in the range of 0.46-1.58 meq/L and 0.49-1.49 meq/L for groundwater samples in summer and rainy seasons respectively (Table 8 \& 9). The Sodium Adsorption Ratio (SAR) parameter evaluates the sodium hazard in relation to calcium and magnesium concentrations. The SAR values are observed less than 10 
meq/L at stations $1 \mathrm{~A}-10 \mathrm{D}$ and $1 \mathrm{~A}-10 \mathrm{D}$ for groundwater samples in summer and rainy seasons. These stations come under the category of 'Excellent'. According to SAR classification, $100 \%$ of the groundwater samples fall within the 'Excellent' category which can be used for irrigation (Table 2).

Table 2. Classification of groundwater samples based on SAR values (Todd 1980).

\begin{tabular}{c|c|c|c}
\hline \multirow{2}{*}{ SAR VALUES (meq/L) } & \multirow{2}{*}{ CLASS } & \multicolumn{2}{|c}{ STATIONS } \\
\cline { 3 - 4 } & & Summer & Rainy \\
\hline$<10$ & Excellent & $1 \mathrm{~A}-10 \mathrm{D}$ & $1 \mathrm{~A}-10 \mathrm{D}$ \\
\hline $10-18$ & Good & -- & -- \\
\hline $18-26$ & Fair & -- & -- \\
\hline$>26$ & Poor & -- & -- \\
\hline
\end{tabular}

\subsection{Percent Sodium (\% Na)}

Percent sodium is used to study the sodium hazard for the assessment of groundwater quality for irrigation purpose. The values of percent sodium are found in the range of 19.2-47.1\% and 20.6-43.3\% of groundwater samples in summer and rainy seasons respectively (Table $8 \& 9$ ). The percent sodium values are observed less than $20 \%$ at station 3B in summer of groundwater samples. This station has only come under the category of 'Excellent'. The values are found in the range of $20-40 \%$ at stations 1A-2D, 3A, 3C-6D, 7B, 8A-10B and 1A-6D, 7B, 8A-10D for summer and rainy seasons respectively. These stations come under the category of 'Good'. The values are found in the range of 40-60\% at stations $7 \mathrm{~A}, 7 \mathrm{D}, 10 \mathrm{C}$ and $10 \mathrm{D}$ in summer and $7 \mathrm{~A}, 7 \mathrm{C}$ and $7 \mathrm{D}$ in rainy seasons. These stations come under the category of 'Permissible' (Table 3). For irrigation purpose, the percentage of sodium is important, because sodium reacts with soil to reduce permeability (Janardhana Raju 2007). When the concentration of sodium is high in irrigation water, sodium ions tend to be absorbed by clay particles, displacing $\mathrm{Mg}^{2+}$ and $\mathrm{Ca}^{2+}$ ions. This exchange process of $\mathrm{Na}^{+}$in water for $\mathrm{Ca}^{2+}$ and $\mathrm{Mg}^{2+}$ in the soil reduces the permeability and eventually results in soil with poor internal drainage. Hence the present study indicates that all the groundwater samples can be used for irrigation.

Table 3. Classification of groundwater samples based on \% Na values (Wilcox 1955).

\begin{tabular}{c|c|c|c}
\hline \multirow{2}{*}{ \%Na VALUES } & \multirow{2}{*}{ CLASS } & \multicolumn{2}{|c}{ STATIONS } \\
\cline { 3 - 4 } & Excellent & Summer & Rainy \\
\hline$<20$ & Good & $\begin{array}{c}1 \mathrm{~A}-2 \mathrm{D}, 3 \mathrm{~A}, 3 \mathrm{C}-6 \mathrm{D}, \\
7 \mathrm{~B}, 8 \mathrm{~A}-10 \mathrm{~B}\end{array}$ & 1A-6D, 7B, 8A-10D \\
\hline $20-40$ & Permissible & $7 \mathrm{~A}, 7 \mathrm{D}, 10 \mathrm{C}$ and 10D & $7 \mathrm{~A}, 7 \mathrm{C}$ and7D \\
\hline $40-60$ & Doubtful & -- & -- \\
\hline $60-80$ & Unsuitable & -- & -- \\
\hline $80-100$ &
\end{tabular}

\subsection{Kelley's Ratio (KR)}

In the present study, Kelly's ratio values are found in the range of $0.13-0.50 \mathrm{meq} / \mathrm{L}$. and $0.14-0.43$ meq/L for groundwater samples in summer and rainy seasons respectively (Table 8 \& 9). Kelly (1940) and Paliwal (1967) introduced an important parameter to evaluate irrigation water quality based on the level of sodium measured against calcium and magnesium. Kelly's ratio is less than one are suitable for irrigation. The $\mathrm{KR}$ value is less than $1 \mathrm{meq} / \mathrm{L}$ at stations $1 \mathrm{~A}-10 \mathrm{D}$ for the groundwater samples in summer and rainy seasons. These stations come under the category of 'Suitable' (Table 4). Hence, the present study, based on KR, indicates that all the groundwater samples are suitable for irrigation. 
Table 4. Classification of groundwater samples based on KR values (Kelly, 1963).

\begin{tabular}{c|c|c|c}
\hline \multirow{2}{*}{ KR VALUES (meq/L) } & \multirow{2}{*}{ CLASS } & \multicolumn{2}{|c}{ STATIONS } \\
\cline { 3 - 4 } & & Summer & Rainy \\
\hline$<1$ & Suitable & $1 \mathrm{~A}-10 \mathrm{D}$ & $1 \mathrm{~A}-10 \mathrm{D}$ \\
\hline $1-2$ & Marginal & -- & -- \\
\hline$>2$ & Unsuitable & -- & -- \\
\hline
\end{tabular}

\subsection{Magnesium Ratio (MR)}

In the present study, the values of magnesium ratio vary from $41-56 \%$ and $43-62 \%$ of groundwater samples in summer and rainy seasons respectively (Table $8 \& 9$ ). In the present study, the values of magnesium ratio less than $50 \%$ are found at stations $2 \mathrm{C}, 2 \mathrm{D}, 3 \mathrm{C}, 4 \mathrm{~A}-4 \mathrm{D}, 5 \mathrm{~A}-5 \mathrm{D}, 6 \mathrm{C}, 7 \mathrm{~A}-7 \mathrm{D}, 8 \mathrm{~A}-8 \mathrm{D}$, $9 \mathrm{~A}, 9 \mathrm{D}, 10 \mathrm{~A}, 10 \mathrm{C}$ and $10 \mathrm{D}$ in summer and 2C, 2D, 4A-4D, 5A, 5C, 6A-6D, 7A-7C, 8A, 8C and 9A-9D in rainy seasons for the groundwater samples. These stations come under the category of 'Suitable' and the remaining sampling stations come under the category of 'Unsuitable' (Table 5).

Table 5. Classification of groundwater samples based on MR values (Paliwal, 1972).

\begin{tabular}{|c|c|c|c|}
\hline \multirow{2}{*}{$\begin{array}{c}\text { MR VALUES } \\
(\%)\end{array}$} & \multirow{2}{*}{ CLASS } & \multicolumn{2}{|l|}{ STATIONS } \\
\hline & & Summer & Rainy \\
\hline$<50$ & Suitable & $\begin{array}{c}2 \mathrm{C}, 2 \mathrm{D}, 3 \mathrm{C}, 4 \mathrm{~A}-4 \mathrm{D}, 5 \mathrm{~A}-5 \mathrm{D}, 6 \mathrm{C}, 7 \mathrm{~A}-7 \mathrm{D}, 8 \mathrm{~A}- \\
8 \mathrm{D}, 9 \mathrm{~A}, 9 \mathrm{D}, 10 \mathrm{~A}, 10 \mathrm{C} \text { and } 10 \mathrm{D}\end{array}$ & $\begin{array}{c}2 \mathrm{C}, 2 \mathrm{D}, 4 \mathrm{~A}-4 \mathrm{D}, 5 \mathrm{~A}, 5 \mathrm{C}, 6 \mathrm{~A}- \\
6 \mathrm{D}, 7 \mathrm{~A}-7 \mathrm{C}, 8 \mathrm{~A} \\
8 \mathrm{C} \text { and } 9 \mathrm{~A}-9 \mathrm{D}\end{array}$ \\
\hline$>50$ & Unsuitable & $\begin{array}{c}1 \mathrm{~A}-1 \mathrm{D}, 2 \mathrm{~A}, 2 \mathrm{~B}, 3 \mathrm{~A}, 3 \mathrm{~B}, 3 \mathrm{D}, 6 \mathrm{~A} \\
6 \mathrm{~B}, 6 \mathrm{D} \text { and } 10 \mathrm{~B}\end{array}$ & $\begin{array}{c}\text { 1A-1D, } 2 \mathrm{~A}, 2 \mathrm{~B}, 3 \mathrm{~A}-3 \mathrm{D} \\
5 \mathrm{~B}, 5 \mathrm{D}, 7 \mathrm{D}, 8 \mathrm{~B} \\
8 \mathrm{D} \text { and } 10 \mathrm{~A}-10 \mathrm{D}\end{array}$ \\
\hline
\end{tabular}

\subsection{Permeability Index (PI)}

Permeability Index values are found in the range of $23.5-52.7 \%$ and $24.9-47.9 \%$ for groundwater samples in summer and rainy seasons respectively (Table $8 \& 9$ ). The PI values are found in the range of $25-50 \%$ at stations $1 \mathrm{~A}-3 \mathrm{~A}, 3 \mathrm{C}-10 \mathrm{D}$ in summer and rainy seasons for groundwater samples. These stations come under the category of class II. If the PI values are less than $25 \%$, the station 3B comes under the category of class III. Class I and II water are categorized good for irrigation (Table 6).

Table 6. Classification of groundwater samples based on PI values.

\begin{tabular}{c|c|c|c}
\hline \multirow{2}{*}{ PI VALUES } & \multirow{2}{*}{ LIMITING VALUES OF PI } & \multicolumn{2}{|c}{ STATIONS } \\
\cline { 3 - 4 } & & Summer & Rainy \\
\hline$>75$ & Class -I & -- & -- \\
\hline $25-50$ & Class -II & $1 \mathrm{~A}-3 \mathrm{~A}, 3 \mathrm{C}-10 \mathrm{D}$ & $1 \mathrm{~A}-3 \mathrm{~A}, 3 \mathrm{C}-10 \mathrm{D}$ \\
\hline$<25$ & Class -III & $3 \mathrm{~B}$ & $3 \mathrm{~B}$ \\
\hline
\end{tabular}

\subsection{Chloro Alkaline Indices (CAI)}

In the present study the values of CAI- 1 lie in the range of -0.153 to 0.726 meq/L and -0.163 to 0.713 meq/L for groundwater samples in summer and rainy seasons respectively. The value of CAI-2 lies in the range of -0.134 to $2.419 \mathrm{meq} / \mathrm{L}$ and -0.180 to $2.644 \mathrm{meq} / \mathrm{L}$ for groundwater in summer and rainy seasons respectively (Table 8 \& 9). Hence, most of the groundwater samples have positive values in CAI-1 and CAI-2, except at stations 5A and 10C. If CAI is negative, there will be an exchange between $\mathrm{Na}+\mathrm{K}$ with calcium and magnesium $(\mathrm{Ca}+\mathrm{Mg})$ in rocks (Jafar Ahamed et al., 2013). If the ratio is positive, there is no base change in CAI. The positive value indicates the absence of base exchange. The 
negative value of the ratio indicates base exchange between sodium and potassium in water with calcium and magnesium in the rocks. From the present study, based on CAI indices, the groundwater is suitable for irrigation purposes.

\subsection{Piper Trilinear Diagram}

Piper (1944) introduced a trilinear diagram that is used to evaluate the geochemical evolution of groundwater and relationship between rock type and water composition. The diagram consists of two triangular fields and a central diamond shaped field. The diamond shaped field between the two triangles is used to represent the composition of water with respect to both cations and anions. The geochemical evolution can be understood by six sub-fields, viz. $\mathrm{Ca}-\mathrm{HCO}_{3}$ type, $\mathrm{Na}-\mathrm{Cl}$ type, mixed $\mathrm{Ca}-$ $\mathrm{Na}-\mathrm{HCO}_{3}$ type, mixed $\mathrm{Ca}-\mathrm{Mg}-\mathrm{Cl}$ type, $\mathrm{Ca}-\mathrm{Cl}$ type and $\mathrm{Na}-\mathrm{HCO}_{3}$ type.

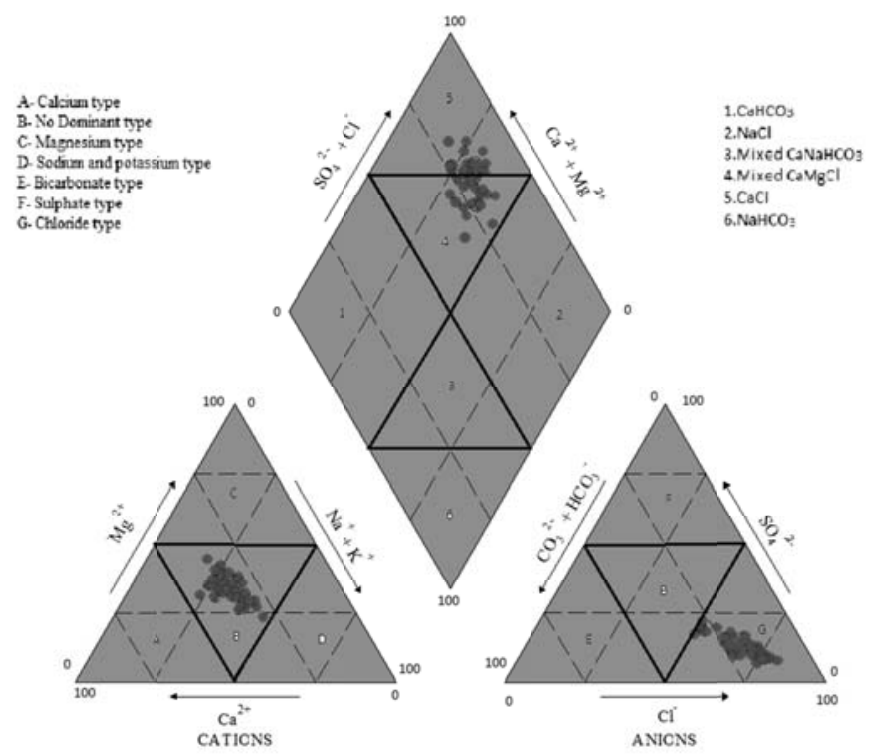

Figure 2. Piper trilinear diagram for groundwater samples during summer seasons (2013, 2014 and 2015)

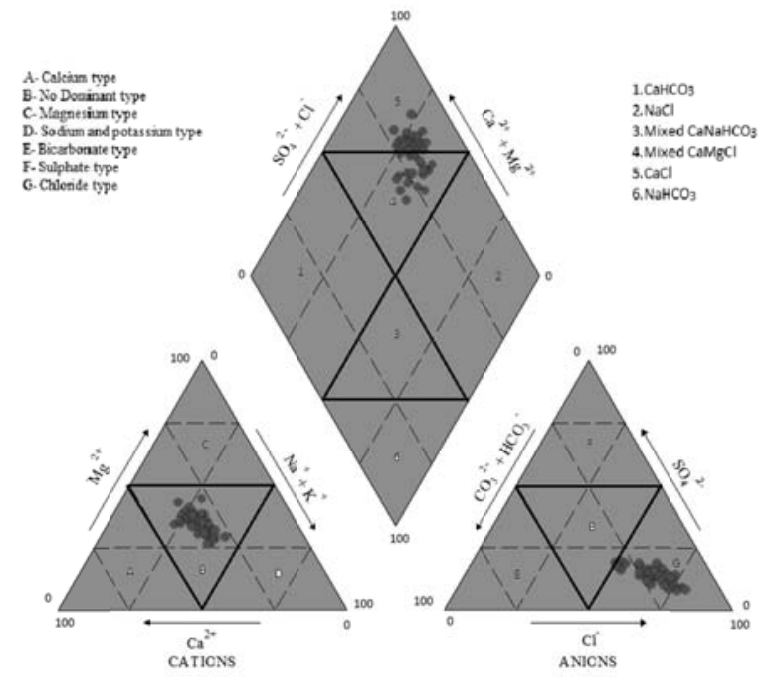

Figure 3. Piper trilinear diagram for groundwater samples during rainy seasons (2013, 2014 and 2015). 
The Piper Trilinear diagram for the groundwater samples is presented in the Fig. 2 \& 3, which clearly explains the variations of cation and anion concentration in the study area. The plot shows that most of the groundwater samples fall in the field type of no dominant type in cation triangle. In the anion triangle majority of the groundwater samples fall in chloride type. In mixed triangle, $50 \%$ of the samples fall in the field of mixed $\mathrm{Ca}-\mathrm{Mg}-\mathrm{Cl}$ type and $\mathrm{Ca}-\mathrm{Cl}$ type predominant in both summer and rainy seasons. This may be due to the geology of the area comprising igneous rocks of crystalline nature.

\subsubsection{USSL Diagram}

The United States Salinity Laboratory (USSL) has constructed a diagram for the classification of irrigation water (Wilcox, 1955) describing 16 classes with reference to SAR as index for sodium hazard and EC as an index for salinity hazard. Sodium and salinity hazards are two important parameters, which can indicate the suitability of water for irrigation uses. (Table 8 \& 9, Fig. 4 \& 5). The USSL diagram highlights that $100 \%$ of the groundwater samples come under the field of C3S1 which indicates that water has high salinity hazard and low sodium alkali hazard in summer and rainy seasons.

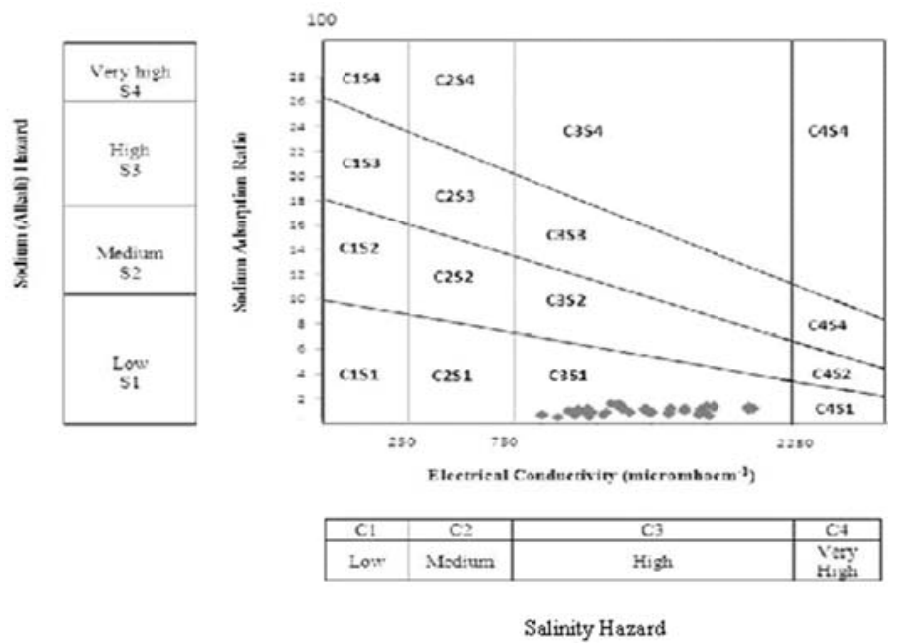

Figure 4. USSL plots for groundwater samples during summer seasons (2013, 2014 and 2015)
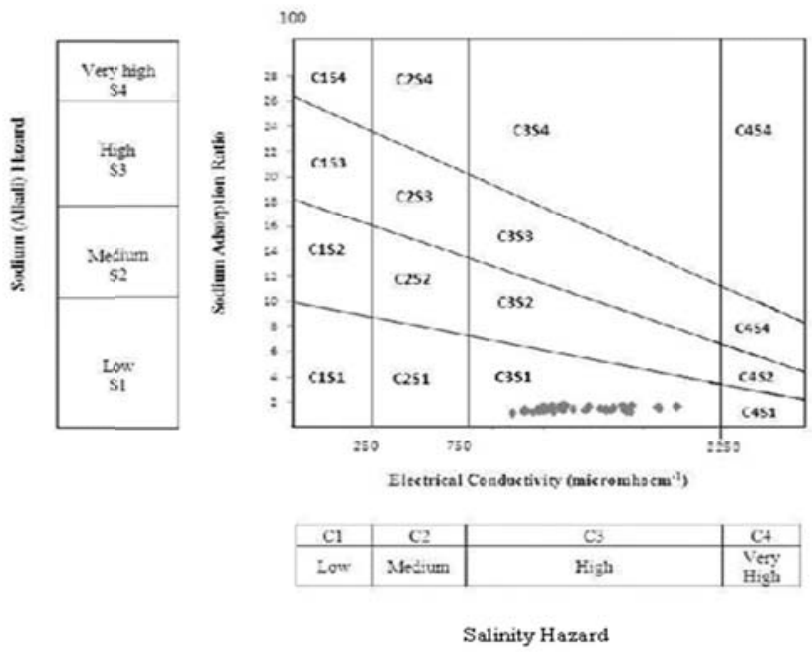

Figure 5. USSL plots for groundwater samples during rainy seasons (2013, 2014 and 2015)

\subsubsection{Wilcox Diagram}

To classify the groundwater suitability for irrigation, Wilcox (1955) constructed a diagram using sodium content as sodium percentage and electrical conductivity. A Wilcox plot can be used to quickly 
determine the viability of water for irrigation purposes. The Wilcox plot is a simple scatter plot of sodium percentage on the $\mathrm{Y}$ axis Vs Electrical conductivity on the X-axis. (Table 7, Fig 6 \& 7). According to the classification of Wilcox, $2 \%$ and $8 \%$ of the groundwater samples fall under the category of 'Excellent' in summer and rainy seasons respectively. $88 \%$ and $92 \%$ of the groundwater samples fall under the category of 'Good' in summer and rainy seasons. However, $10 \%$ of the samples come under the category of 'Permissible' in summer seasons.

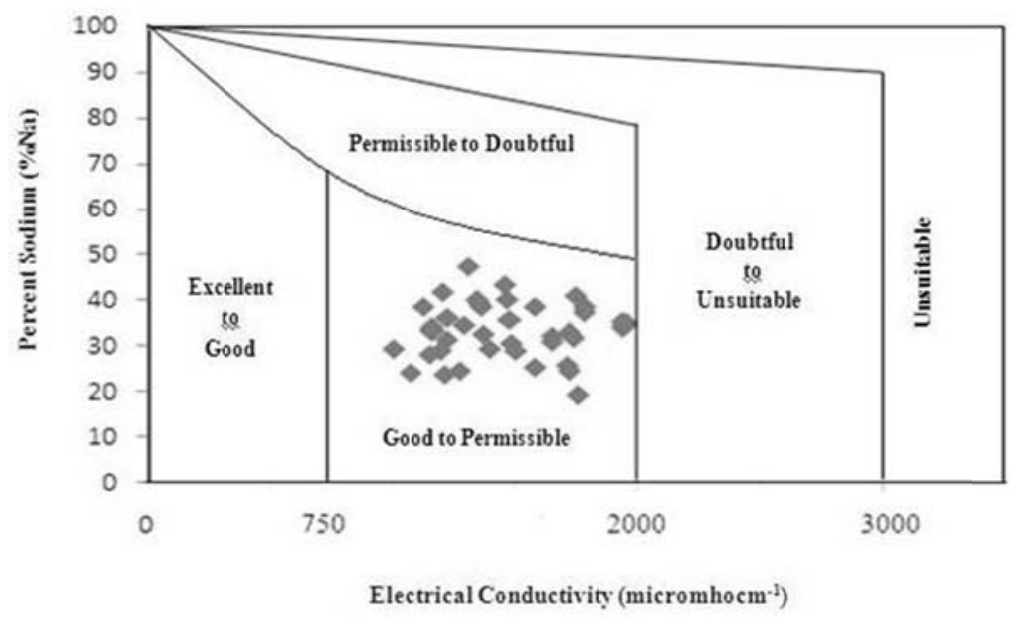

Figure 6. Wilcox plots for groundwater samples in summer seasons (2013, 2014 and 2015.

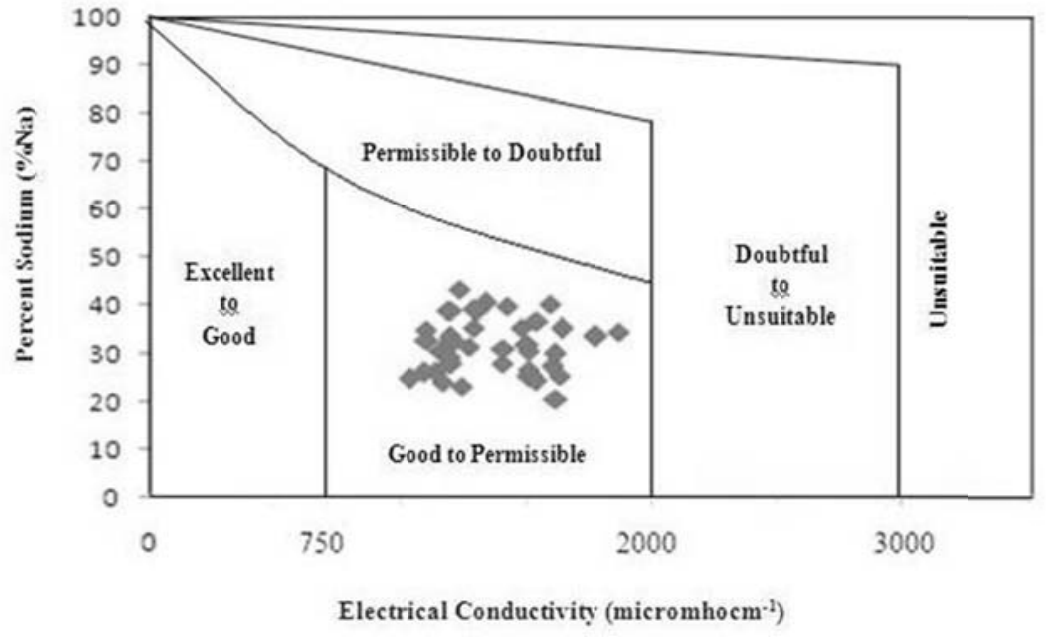

Figure 7. Wilcox plots for groundwater samples in rainy seasons (2013, 2014 and 2015)

Table 7. Classification of groundwater samples based on \% Na values (Wilcox 1955).

\begin{tabular}{c|c|c|c|c|c}
\hline \multirow{2}{*}{ \% Na } & \multirow{2}{*}{ Water Class } & \multicolumn{2}{|c|}{ No of Samples } & \multicolumn{2}{c}{ \% of Samples } \\
\cline { 3 - 6 } & & Summer & Rainy & Summer & Rainy \\
\hline $0-20$ & Excellent & 1 & -- & 2 & 8 \\
\hline $20-40$ & Good & 35 & 37 & 88 & 92 \\
\hline $40-60$ & Permissible & 4 & 3 & 10 & -- \\
\hline $60-80$ & Doubtful & -- & -- & -- & -- \\
\hline$>80$ & Unsuitable & -- & -- & -- & -- \\
\hline
\end{tabular}


Table 8. The mean values of irrigation water quality for groundwater samples during April 2013, 2014 and 2015.

\begin{tabular}{|c|c|c|c|c|c|c|c|c|}
\hline STATIONS & $\mathrm{RSC}$ & SAR & $\% \mathrm{Na}$ & $\mathrm{KR}$ & MR & PI & CAI 1 & CAI 2 \\
\hline $1 \mathrm{~A}$ & -5.15 & 1.24 & 32.4 & 0.32 & 56 & 39.7 & 0.137 & 0.121 \\
\hline 1B & -5.37 & 0.88 & 29.1 & 0.22 & 52 & 34.5 & 0.287 & 0.280 \\
\hline $1 \mathrm{C}$ & -4.81 & 0.84 & 28.7 & 0.24 & 55 & 34.6 & 0.494 & 0.801 \\
\hline 1D & -4.72 & 1.06 & 33.0 & 0.31 & 55 & 37.7 & 0.395 & 0.640 \\
\hline $2 \mathrm{~A}$ & -5.78 & 1.11 & 32.6 & 0.27 & 55 & 36.5 & 0.476 & 0.702 \\
\hline $2 \mathrm{~B}$ & -5.35 & 1.16 & 31.9 & 0.29 & 54 & 38.3 & 0.507 & 0.755 \\
\hline $2 \mathrm{C}$ & -4.99 & 0.73 & 24.3 & 0.21 & 46 & 32.3 & 0.698 & 1.356 \\
\hline $2 \mathrm{D}$ & -3.96 & 0.66 & 29.0 & 0.20 & 43 & 35.3 & 0.454 & 0.597 \\
\hline $3 \mathrm{~A}$ & -7.30 & 0.76 & 25.0 & 0.18 & 56 & 28.1 & 0.384 & 0.419 \\
\hline $3 \mathrm{~B}$ & -8.22 & 0.58 & 19.2 & 0.13 & 55 & 23.5 & 0.604 & 0.781 \\
\hline $3 \mathrm{C}$ & -4.20 & 0.92 & 31.3 & 0.28 & 49 & 37.8 & 0.59 & 1.298 \\
\hline $3 \mathrm{D}$ & -4.51 & 0.54 & 23.7 & 0.15 & 53 & 31.6 & 0.574 & 0.694 \\
\hline $4 \mathrm{~A}$ & -5.52 & 0.68 & 25.4 & 0.17 & 47 & 31.2 & 0.726 & 1.410 \\
\hline $4 \mathrm{~B}$ & -6.57 & 0.80 & 24.5 & 0.19 & 49 & 30.4 & 0.579 & 0.969 \\
\hline $4 \mathrm{C}$ & -3.08 & 0.46 & 24.1 & 0.15 & 41 & 36.5 & 0.653 & 0.781 \\
\hline $4 \mathrm{D}$ & -3.68 & 0.71 & 28.1 & 0.22 & 43 & 37.8 & 0.567 & 0.905 \\
\hline $5 \mathrm{~A}$ & -6.26 & 1.47 & 39.2 & 0.37 & 48 & 38.8 & -0.059 & -0.075 \\
\hline $5 \mathrm{~B}$ & -6.55 & 0.87 & 28.9 & 0.21 & 50 & 30.9 & 0.391 & 0.480 \\
\hline $5 \mathrm{C}$ & -4.25 & 0.99 & 38.3 & 0.30 & 42 & 38.7 & 0.007 & 0.008 \\
\hline $5 \mathrm{D}$ & -4.36 & 0.91 & 34.3 & 0.26 & 49 & 37.6 & 0.431 & 0.718 \\
\hline $6 \mathrm{~A}$ & -6.47 & 1.09 & 33.8 & 0.26 & 51 & 34.3 & 0.637 & 1.758 \\
\hline $6 \mathrm{~B}$ & -7.03 & 1.15 & 34.6 & 0.27 & 55 & 33.6 & 0.612 & 1.865 \\
\hline $6 \mathrm{C}$ & -3.78 & 0.91 & 36.0 & 0.27 & 47 & 40.3 & 0.090 & 0.081 \\
\hline $6 \mathrm{D}$ & -5.98 & 0.97 & 31.5 & 0.25 & 51 & 33.1 & 0.692 & 2.419 \\
\hline $7 \mathrm{~A}$ & -5.19 & 1.41 & 40.7 & 0.36 & 48 & 41.6 & 0.493 & 1.231 \\
\hline $7 \mathrm{~B}$ & -6.14 & 1.25 & 35.2 & 0.31 & 48 & 37.1 & 0.631 & 1.651 \\
\hline $7 \mathrm{C}$ & -3.25 & 1.07 & 43.2 & 0.33 & 48 & 45.0 & 0.579 & 1.539 \\
\hline $7 \mathrm{D}$ & -2.90 & 1.58 & 47.1 & 0.50 & 44 & 52.7 & 0.319 & 0.530 \\
\hline $8 \mathrm{~A}$ & -5.43 & 1.22 & 40.0 & 0.32 & 44 & 38.5 & 0.049 & 0.059 \\
\hline $8 \mathrm{~B}$ & -6.02 & 0.90 & 30.2 & 0.23 & 46 & 31.9 & 0.441 & 0.641 \\
\hline $8 \mathrm{C}$ & -4.41 & 0.81 & 33.7 & 0.23 & 46 & 35.9 & 0.380 & 0.56 \\
\hline $8 \mathrm{D}$ & -3.97 & 0.88 & 34.1 & 0.27 & 50 & 38.4 & 0.466 & 0.787 \\
\hline 9A & -5.98 & 1.26 & 38.2 & 0.32 & 44 & 37.5 & 0.298 & 0.481 \\
\hline 9B & -7.10 & 0.97 & 30.8 & 0.23 & 48 & 30.9 & 0.488 & 0.875 \\
\hline $9 \mathrm{C}$ & -4.30 & 0.94 & 35.5 & 0.27 & 47 & 38.6 & 0.472 & 0.811 \\
\hline $9 \mathrm{D}$ & -4.06 & 1.15 & 38.4 & 0.34 & 46 & 42.2 & 0.478 & 0.958 \\
\hline $10 \mathrm{~A}$ & -5.74 & 1.16 & 38.4 & 0.29 & 48 & 37.0 & -0.153 & -0.134 \\
\hline 10B & -6.82 & 1.39 & 37.3 & 0.33 & 51 & 37.1 & 0.026 & 0.030 \\
\hline $10 \mathrm{C}$ & -3.40 & 1.24 & 41.7 & 0.37 & 50 & 46.4 & -0.137 & -0.114 \\
\hline $10 \mathrm{D}$ & -4.73 & 1.47 & 40.1 & 0.41 & 49 & 43.5 & 0.181 & 0.257 \\
\hline
\end{tabular}

All the values are expressed in meq/L except percent sodium, PI and MR in \% 
Table 9. The mean values of irrigation water quality for groundwater samples during December 2013, 2014 and 2015.

\begin{tabular}{|c|c|c|c|c|c|c|c|c|}
\hline STATIONS & RSC & SAR & $\% \mathrm{Na}$ & $\mathrm{KR}$ & MR & PI & CAI 1 & CAI 2 \\
\hline $1 \mathrm{~A}$ & -4.67 & 1.13 & 31.5 & 0.31 & 56 & 39.9 & 0.192 & 0.204 \\
\hline 1B & -4.27 & 0.88 & 31.1 & 0.24 & 55 & 38.1 & 0.292 & 0.333 \\
\hline $1 \mathrm{C}$ & -5.41 & 0.90 & 27.8 & 0.24 & 62 & 33.5 & 0.437 & 0.850 \\
\hline $1 \mathrm{D}$ & -5.10 & 0.91 & 30.5 & 0.25 & 54 & 34.2 & 0.386 & 0.683 \\
\hline $2 \mathrm{~A}$ & -5.19 & 0.95 & 31.7 & 0.25 & 54 & 35.9 & 0.509 & 0.936 \\
\hline $2 \mathrm{~B}$ & -5.38 & 0.82 & 27.3 & 0.21 & 54 & 33.9 & 0.573 & 1.026 \\
\hline $2 \mathrm{C}$ & -5.25 & 0.61 & 23.3 & 0.17 & 45 & 28.7 & 0.697 & 1.904 \\
\hline $2 \mathrm{D}$ & -4.86 & 0.61 & 26.1 & 0.17 & 50 & 31.1 & 0.423 & 0.619 \\
\hline $3 \mathrm{~A}$ & -7.05 & 0.74 & 25.1 & 0.18 & 55 & 28.0 & 0.384 & 0.541 \\
\hline $3 \mathrm{~B}$ & -7.60 & 0.60 & 20.6 & 0.14 & 54 & 24.9 & 0.567 & 0.932 \\
\hline $3 \mathrm{C}$ & -4.55 & 0.92 & 31.3 & 0.27 & 52 & 36.4 & 0.533 & 1.265 \\
\hline $3 \mathrm{D}$ & -4.74 & 0.57 & 24.2 & 0.16 & 52 & 30.7 & 0.559 & 1.030 \\
\hline $4 \mathrm{~A}$ & -5.35 & 0.67 & 25.4 & 0.17 & 46 & 31.5 & 0.713 & 1.901 \\
\hline $4 \mathrm{~B}$ & -6.52 & 0.79 & 24.3 & 0.19 & 50 & 30.2 & 0.532 & 0.988 \\
\hline $4 \mathrm{C}$ & -3.64 & 0.49 & 24.7 & 0.15 & 47 & 33.9 & 0.584 & 0.936 \\
\hline $4 \mathrm{D}$ & -4.31 & 0.58 & 26.1 & 0.17 & 50 & 32.8 & 0.558 & 1.059 \\
\hline $5 \mathrm{~A}$ & -5.74 & 1.49 & 39.4 & 0.39 & 44 & 40.2 & -0.023 & -0.040 \\
\hline $5 \mathrm{~B}$ & -6.60 & 0.78 & 26.8 & 0.19 & 52 & 29.5 & 0.430 & 0.748 \\
\hline $5 \mathrm{C}$ & -4.71 & 0.87 & 33.5 & 0.25 & 45 & 35.4 & 0.051 & 0.078 \\
\hline $5 \mathrm{D}$ & -4.69 & 0.83 & 32.7 & 0.24 & 52 & 34.7 & 0.454 & 1.045 \\
\hline $6 \mathrm{~A}$ & -6.52 & 1.03 & 33.4 & 0.25 & 53 & 33.3 & 0.583 & 1.758 \\
\hline $6 \mathrm{~B}$ & -6.45 & 1.15 & 34.1 & 0.28 & 54 & 34.8 & 0.610 & 2.123 \\
\hline $6 \mathrm{C}$ & -3.68 & 0.91 & 35.0 & 0.27 & 53 & 40.8 & 0.034 & 0.033 \\
\hline $6 \mathrm{D}$ & -5.67 & 0.92 & 30.7 & 0.24 & 56 & 33.2 & 0.679 & 2.644 \\
\hline $7 \mathrm{~A}$ & -5.25 & 1.41 & 40.3 & 0.37 & 48 & 41.3 & 0.434 & 1.237 \\
\hline $7 \mathrm{~B}$ & -6.17 & 1.23 & 34.4 & 0.3 & 50 & 36.8 & 0.606 & 1.956 \\
\hline $7 \mathrm{C}$ & -3.68 & 0.92 & 40.4 & 0.28 & 48 & 40.9 & 0.576 & 1.890 \\
\hline $7 \mathrm{D}$ & -3.52 & 1.42 & 43.3 & 0.43 & 52 & 47.9 & 0.267 & 0.531 \\
\hline $8 \mathrm{~A}$ & -5.43 & 1.26 & 39.6 & 0.33 & 46 & 39.0 & -0.020 & -0.030 \\
\hline $8 \mathrm{~B}$ & -6.65 & 0.83 & 28.0 & 0.21 & 53 & 29.0 & 0.429 & 0.882 \\
\hline $8 \mathrm{C}$ & -4.96 & 0.75 & 29.4 & 0.21 & 48 & 32.9 & 0.434 & 0.850 \\
\hline $8 \mathrm{D}$ & -4.19 & 0.76 & 32.9 & 0.23 & 52 & 35.7 & 0.429 & 0.882 \\
\hline $9 \mathrm{~A}$ & -6.36 & 1.21 & 36.6 & 0.30 & 47 & 35.6 & 0.259 & 0.521 \\
\hline $9 \mathrm{~B}$ & -7.17 & 0.90 & 29.9 & 0.22 & 48 & 29.2 & 0.480 & 1.243 \\
\hline $9 \mathrm{C}$ & -4.36 & 0.87 & 35.3 & 0.25 & 48 & 37.3 & 0.468 & 1.055 \\
\hline $9 \mathrm{D}$ & -3.89 & 1.11 & 38.9 & 0.34 & 43 & 42.3 & 0.401 & 0.988 \\
\hline $10 \mathrm{~A}$ & -6.27 & 1.07 & 35.4 & 0.26 & 52 & 34.4 & -0.152 & -0.180 \\
\hline $10 \mathrm{~B}$ & -7.15 & 1.33 & 35.2 & 0.31 & 53 & 35.6 & 0.116 & 0.209 \\
\hline $10 \mathrm{C}$ & -4.02 & 1.13 & 38.8 & 0.33 & 51 & 42.3 & -0.163 & -0.170 \\
\hline 10D & -5.14 & 1.42 & 39.0 & 0.39 & 52 & 41.2 & 0.139 & 0.259 \\
\hline
\end{tabular}

All the values are expressed in meq/L except percent sodium, PI and MR in \%

\section{Conclusion}

In the present study the values of Percent Sodium, Sodium Adsorption Ratio, Residual Sodium Carbonate, Permeability Index, Kelly's Ratio and Chloro alkaline Indices are found in the permissible 
limit of WHO standards in summer and rainy seasons. Based on the irrigation water quality parameters, the ground water can be used for the irrigation purposes.

\section{References}

1. American Public Health Association (1995). Standards methods for examination water and waste water (19th Edition). Washington, (APHA), D.C.

2. Dash A, Das H K and Mishra B. (2014). Hydrogeochemistry and groundwater quality in and around Joda of Keonjhar district, Odisha, India. IJISR., 12, (2): 409-419

3. Jafar Ahamed A, Ananthakrishnan S, Loganathan K and Manikandan K. (2013). Assessment of groundwater quality for irrigation use in Alathur block, Perambalur district, Tamilnadu, South India. Appl Water Sci., 33 (4): 763-771.

4. Janardhana Raju N, Reddy T V K, Kotaiah B and Nayudu P T. (1992). A study on seasonal variations of groundwater quality in upper Gunjanaeru river basin, Cuddapah District, Andhra Pradesh. Fresenius Environ Bull., 1, 98-103.

5. Paliwal K.V. (1972). Irrigation with Saline water I.A.R.I., Monograph No. 2 (New Series), New Delhi, 198

6. Piper A M. (1944). A graphic procedure in the geochemical interpretation of water analysis. American Geophysical Union Transactions, 25, 914-923.

7. Vasanthavigar M, Srinivasamoorthy K, Vijayaragavan K, Rajiv Ganthi R, Chidambaram S, Anandhan P, Manivannan R and Vasudevan S. (2010). Application of water quality index for groundwater quality assessment: Thirumanimuttar sub-basin, Tamilnadu, India. Environ Monit Assess., 171, (1): 595-609.

8. WHO (World Health Organization) (2011). International standards for drinking water, Geneva

9. Wilcox, L.V. (1955). Classification and use of irrigation water. Washington, United States department of agriculture, Circ.969. 